ТЕОРЕТИЧНІ ПРОБЛЕМИ РОЗВИТКУ НАЦІОНАЛЬНОЇ ЕКОНОМІКИ

УДК 334.7:658.115

DOI: 10.25140/2411-5215-2019-2(18)-52-59

Оксана Чумак

\title{
НОРМАТИВНО-ПРАВОВЕ ІНТЕРПРЕТУВАННЯ ТА ЕКОНОМІЧНА ІДЕНТИФІКАЦІЯ ОБ'СКТІВ ДЕРЖАВНОЇ ВЛАСНОСТІ
}

\author{
Оксана Чумак
}

\section{НОРМАТИВНО-ПРАВОВОЕ ИНТЕРПРЕТИРОВАНИЕ И ЭКОНОМИЧЕСКАЯ ИДЕНТИФИКАЦИЯ ОБЪЕКТОВ ГОСУДАРСТВЕННОЙ СОБСТВЕННОСТИ \\ Oksana Chumak}

\section{REGULATORY-LEGAL INTERPRETATION AND ECONOMIC IDENTIFICATION OF OBJECTS OF STATE PROPERTY}

У статті проаналізовано вітчизняні та зарубіжні нормативно-правові документи, за якими визначаються основні класифікаційні ознаки об'єктів та видів державної власності. Систематизовано та охарактеризовано види підприємств державної форми власності та інституціональних одиниць державного сектору економіки в розрізі різних правових ознак. Розглянуто порядок управління корпоративним правами об'єктів державної власності. Розкрито сутність суб' єктів господарювання з державною часткою у статутному капіталі за правовим форматом. Наведено огляд основних моделей власності, за якими здійснюється управління державними підприємствами за зарубіжною практикою. Узагальнено напрями забезпечення ефективної нормативно-правової бази для державних підприємств з позииії еталону ОЕСР.

Ключові слова: класифікачія; інституціональна одиниия; державна власність; правова форма; державне підприємство.

Рис.: 2. Бібл.: 11 .

В статье осуществлен анализ отечественных и зарубежных нормативно-правовых документов, определяющие основные классификационные признаки объектов и видов государственной собственности. Систематизировань и охарактеризованы виды предприятий государственной формы собственности и институциональных единии государственного сектора экономики в разрезе различных правовых признаков. Рассмотрен порядок управления корпоративными правами объектов государственной собственности. Раскрыта суть субъектов хозяйствования, имеющчих государственную долю в уставном капитале по правовому формату. Выполнен обзор основных моделей собственности, по которым осуществляется управление государственными предприятиями, согласно зарубежной практики. Обобшены направления обеспечения эффективной нормативно-правовой базы для государственных предприятий с позиции эталона ОЭСР.

Ключевые слова: классификация; институциональная единица; государственная собственность; правовая форма; государственное предприятие.

Рис.: 2. Библ.: 11.

The article analyzes domestic and foreign regulatory documents that determine main classification features of objects and types of state property. The types of enterprises of state ownership and institutional units of the public sector of the economy are systematized and characterized in the context of various legal features. The procedure for managing corporate rights of state property is considered. The essence of business entities having a state share in the authorized capital in legal format is disclosed. A review of the main ownership models for the management of state-owned enterprises is carried out, according to foreign practice. The directions of ensuring an effective regulatory framework for state-owned enterprises from the perspective of the OECD benchmark are summarized.

Keywords: classification; institutional unit; state property; legal form; state-owned enterprise.

Fig.: 2. References: 11

JEL Classification: L30; L32

Постановка проблеми. У багатьох країнах світу до складу державної власності входять об’єкти різної значущості та різних функцій, які забезпечують соціальноекономічний розвиток. Державні підприємства дедалі частіше провадять економічну діяльність та транскордонні інвестиції на глобальному ринку поряд із приватними підприємствами, що означає наявність їхнього внутрішнього й міжнародного впливу. В Україні нині тривають процеси реформування державних підприємств через приватизацію, удосконалення корпоративного управління, реструктуризацію, ліквідацію, реорганізацію тощо. Як свідчить закордонна практика, тенденція урядів частково позбавитись частки власності може спостерігатися зниженням частки державних підприємств у національній економіці, проте не обов'язково означає відповідне зниження здатності уряду здійснювати вплив на діяльність цих підприємств. Проблема уп-

(C) Чумак О. B., 2019 
ТЕОРЕТИЧНІ ПРОБЛЕМИ РОЗВИТКУ НАЦІОНАЛЬНОЇ ЕКОНОМІКИ

равління державною власністю в Україні носить комплексний характер та вимагає розвитку наукових підходів до ії вирішення під час національного реформування за умов неоекономіки, глобалізаційних та інтеграційних процесів у світове співтовариство. Для систематизації суб'єктів державного сектору вбачаємо за доцільне їх групування як інституційних одиниць за основними класифікаційними ознаками.

Аналіз останніх досліджень і публікацій. До дослідження питання класифікації та інтерпретації об'єктів державної власності привертали увагу вчені економічної та правової галузі: М. Д. Білик, С. С. Гасанов, О.М.Іваницька, О.М.Головінов, П.В.Круш, Р. А. Муха, О. О. Кравчук. Велику увагу приділено уточненню та узагальненню класифікаційних ознак, економічних та юридичних трактувань, проте останніми роками інтеграції вітчизняного законодавства та економічних зв'язків зумовила необхідність відповідності зарубіжним правовим нормам та досвіду класифікацій об'єктів державної власності. Це спричиняє необхідність проаналізувати структуру державного сектору Україні відповідно до правового поля, вітчизняного та зарубіжного досвіду за сучасних умов.

Вищенаведене є основою для визначення мети дослідження, як уточнення правового й економічного інтерпретування об’єктів державної власності, систематизації та структурування таких об'єктів відповідно до чинного правового поля в Україні та за кордоном.

Виділення недосліджених частин загальної проблеми. На сьогодні в науковому полі питання ідентифікації об'єктів державної власності та розкриття їх економічної інтерпретації розкриваються локально - за окремими класифікаційними ознаками чи видами, що не дозволяє отримати цілісної картини про суб'єктів державної форми власності. Це питання регламентовано низкою нормативно-правових актів різних урядових установ і відомств, враховуючи зарубіжні норми, тому систематизація інформації про об'єкти державної власності $є$ вимогою часу в умовах реформування державних підприємств.

Мета статті. Метою статті є систематизація нормативно-правового підгрунтя щодо ідентифікації об’єктів державної власності та розкриття їх економічної інтерпретації для об’єктивної оцінки діяльності державних підприємств.

Основний текст. Як зауважує Г. М. Тарасюк, з переходом до ринкової економіки інтерес науковців до теоретичних та прикладних питань управління державними підприємствами послабився, законодавче поле було недосконалим, зниження ролі державного управління, дезорганізація у здійсненні важливих функцій виконавчої влади багато в чому стали наслідком хибного підходу до економічних реформ [1]. За період реформування економіки України, пов'язаного 3 масовою приватизацією (1992-1998рр.), форму власності змінили 62000 державних підприємств, що, у свою чергу, позначилося на істотному зниженні ефективності їхньої діяльності, погіршенні фінансового стану, доведення до межі банкрутства. М. Д. Білик досліджувала механізм управління фінансами державних підприємств через відносини 3 державою та іншими суб'єктами господарювання [2, с. 30] для підвищення ефективності й результативності їхньої діяльності. Станом на початок 2014 року науковцями державний сектор характеризується як неоднорідний щодо ефективності фінансового управління, оскільки понад 500 підприємств із 4000, у яких понад 50 \% активів належить державі, перебували на стадії банкрутства, а у більше ніж 400 підприємств розмір державних корпоративних прав є недостатнім для реалізації державою повноважень із управління ними [3].

Система національних рахунків (п. 77 СНР) [4] визначає підприємство як виробника товарів і послуг, що є економічним трансактором, що має автономію щодо прийняття фінансових та інвестиційних рішень, а також повноваження та відповідальність за розподіл ресурсів для виробництва товарів та послуг і може займатися однією або кількома виробничими видами діяльності. У п. 78 зазначено, що підприємство може бути корпорацією (або квазікорпорацією), некомерційною установою або непідконтрольним 
ТЕОРЕТИЧНІ ПРОБЛЕМИ РОЗВИТКУ НАЦІОНАЛЬНОЇ ЕКОНОМІКИ

підприємством. СНР згідно з класифікацією інституційних одиниць розрізняє п'ять секторів (груп) інституційних одиниць, які є однорідними з погляду функцій, які вони виконують в економічному процесі, та способу фінансування витрат. Такими групами є: сектор загального державного управління; сектор нефінансових корпорацій, тобто підприємства, які виробляють продукти та надають нефінансові послуги; сектор фінансових корпорацій; сектор домашніх господарств; сектор некомерційних організацій, які обслуговують домашні господарства. Отже, підприємства (установи, організації) державного сектору економіки належать до різних секторів, що вирізняються згідно із класифікацією системи національних рахунків. При віднесенні інституційних одиниць до певного сектору або підсектору економіки України враховується їхня організаційноправова форма господарювання та вид економічної діяльності, перелік яких визначають відповідно до Класифікації організаційно-правових форм господарювання (КОПФГ). Згідно з Класифікацією інституційних секторів економіки [5] основними видами юридичних осіб є корпорації (включаючи квазікорпорації), некомерційні організації, органи державного управління (рис. 1).

\section{Інституційна одиниця - юридична особа}

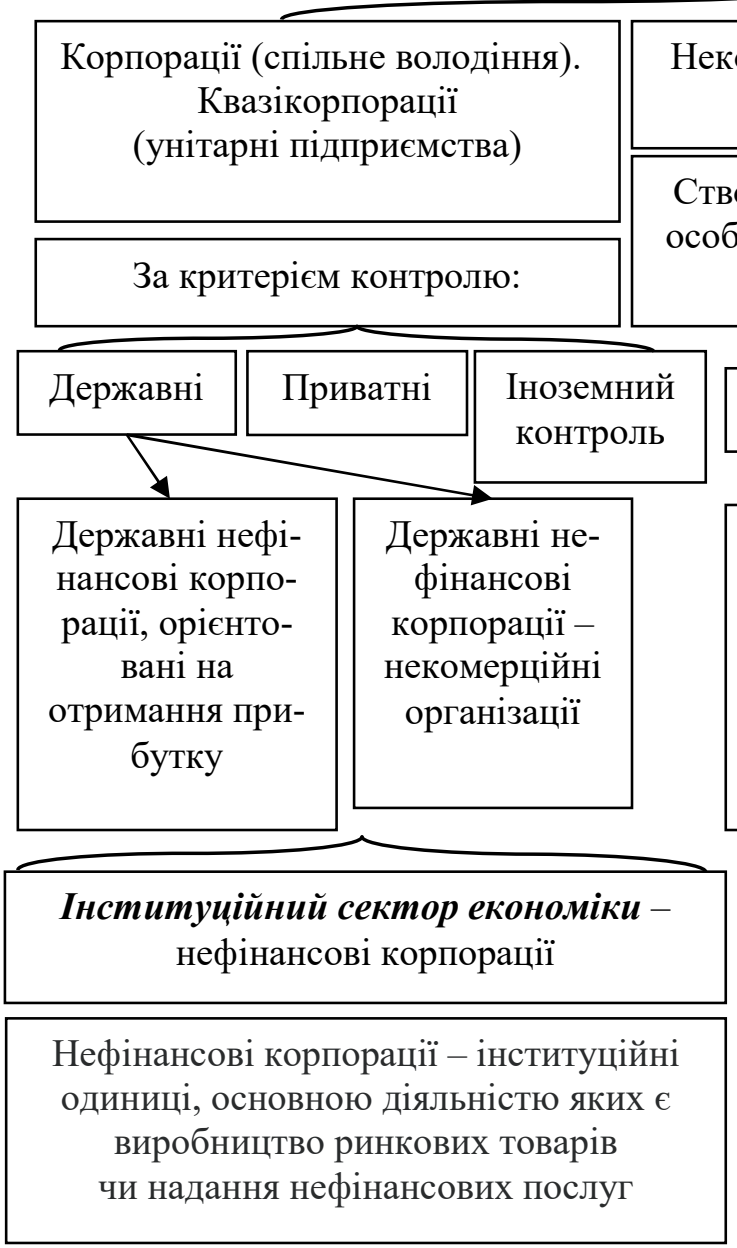

Органи державного управління (ОДУ) здійснюють функції законодавчої, виконавчої та судової влади

Рис. 1. Класифікація інституиіональних одиниць державного сектору економіки

Підприємства державного нефінансового сектору економіки поділено на корпорації (держава виступає співвласником) та квазікорпорації (держава єдиний власник), оскільки їм притаманні такі основні риси корпорацій, як можливість руху фінансових потоків і капіталу в усталеній системі відносин. У Розділі 4(S) Класифікації інституційних 
ТЕОРЕТИЧНІ ПРОБЛЕМИ РОЗВИТКУ НАЦІОНАЛЬНОЇ ЕКОНОМІКИ

секторів економіки України [5] здійснено такий розподіл: S.1 Економіка в цілому; S.11 Нефінансові корпорації; S.11001 Державні нефінансові корпорації; S.110011 Державні нефінансові корпорації - ООП; S.110012 Державні нефінансові корпорації - НКО.

Відповідно до цієї класифікації нефінансові корпорації включають, зокрема, усі нефінансові корпорації (як вони визначені у СНР, а не тільки корпорації, зареєстровані як акціонерні товариства) незалежно від того, резидентами яких країн є їхні акціонери. Другий критерій стосується контролю, і він дозволяє ідентифікувати: державні нефінансові корпорації; приватні нефінансові корпорації; нефінансові корпорації під іноземним контролем. У розділі S.11001 [5] здійснено опис державних нефінансових корпорацій, до яких віднесено корпорації та квазікорпорації, які $\epsilon$ резидентами й контролюються органами державного управління; при цьому контроль за корпорацією визначається шляхом розроблення генеральної політики корпорації та призначення директорів (якщо існує така необхідність).

Для здійснення контролю більш ніж половиною голосів акціонерів органи державного управління не обов'язково повинні володіти акціями, які надають право голосу. Державна корпорація, наприклад, може бути дочірньою корпорацією іншої державної корпорації, основна частина голосів якої належить цьому органу, а також квазікорпорацією, яка перебуває в безпосередній власності органів державного управління. Корпорації визначаються як інституційні одиниці, що створені спеціально з метою ринкового виробництва товарів та послуг і є джерелом прибутку чи іншої фінансової вигоди для своїх власників (термін «корпорація» у контексті Класифікації інституційних секторів економіки [5] використовується як узагальнюючий термін для всіх організацій, орієнтованих на отримання прибутку (ООП)). До квазікорпорацій віднесено унітарні підприємства, тобто такі, що створюються одним засновником (власником). Кожна квазікорпорація має повний набір рахунків, який надає можливість повністю визначати потоки доходів і капіталу між нею та власником. Квазікорпораціями є державні, комунальні та приватні підприємства, підприємства споживчої кооперації, а також іноземні підприємства.

У Главі 8 Господарського кодексу України [6] визначаються правові засади регулювання господарських відносин підприємств залежно від способу утворення (заснування) та формування статутного капіталу: державне комерційне, казенне та унітарне. Державні унітарні підприємства діють як державні комерційні підприємства або казенні підприємства. Майно державного унітарного підприємства перебуває в державній власності й закріплюється за таким підприємством на праві господарського відання чи праві оперативного управління. У процесі створення та організації діяльності державних підприємств за участю держави, остання може виступити в ролі: засновника, співзасновника та власника пакету акцій. Нормативно державне підприємство визначено таким, що діє на основі державної власності. Залежно від способу утворення (заснування) та формування статутного капіталу в Україні діють унітарні та корпоративні державні підприємства. Державні унітарні підприємства діють як державні комерційні підприємства або казенні підприємства. Казенне підприємство створюється за рішенням Кабінету Міністрів України, майно закріплюється за ним на праві оперативного управління в обсязі, зазначеному в статуті підприємства. Таким чином, до підприємств державної форми власності віднесено: державні комерційні підприємства, казенні підприємства, державні акціонерні товариства, акції яких перебувають у державній власності. Держава та орган, до сфери управління якого входить державне комерційне підприємство, не несуть відповідальності за його зобов'язаннями, крім випадків, передбачених законодавчими актами. Управління корпоративним правами здійснюється в особі уряду, Фонду державного майна України, міністерств та інших центральних і місцевих органів виконавчої влади. 
ТЕОРЕТИЧНІ ПРОБЛЕМИ РОЗВИТКУ НАЦІОНАЛЬНОЇ ЕКОНОМІКИ

Фонд державного майна України [7] (ФДМУ) формує та веде Єдиний реєстр об'єктів державної власності відповідно до Закону України «Про управління об'єктами державної власності», постанов Уряду від 14 квітня 2004 року № 467 «Про затвердження Положення про Єдиний реєстр об'єктів державної власності» та від 30 листопада 2005 року № 1121 «Про затвердження Методики проведення інвентаризації об’єктів державної власності» та інших нормативно-правових актів. Фондом запроваджено на єдиних методологічних засадах збір інформації про об'єкти державної власності, відповідно до якого Фонд щоквартально вносить зміни до Реєстру. Станом на 1 січня 2019 року за інформацією, наданою суб'єктами управління (за підсумками проведеної інвентаризації об'єктів державної власності), у Реєстрі обліковуються:

- 21,2 тис. юридичних осіб, які діють лише на основі державної власності й належать до сфери управління відповідного суб'єкта управління;

- 455 господарських організацій із корпоративними правами держави;

- понад 1 млн об'єктів державного майна.

За Класифікатором організаційно-правових форм господарювання (КОПФГ) [8] підприємства 3 державною часткою власності можуть мати формати, як подано на рис. 2.

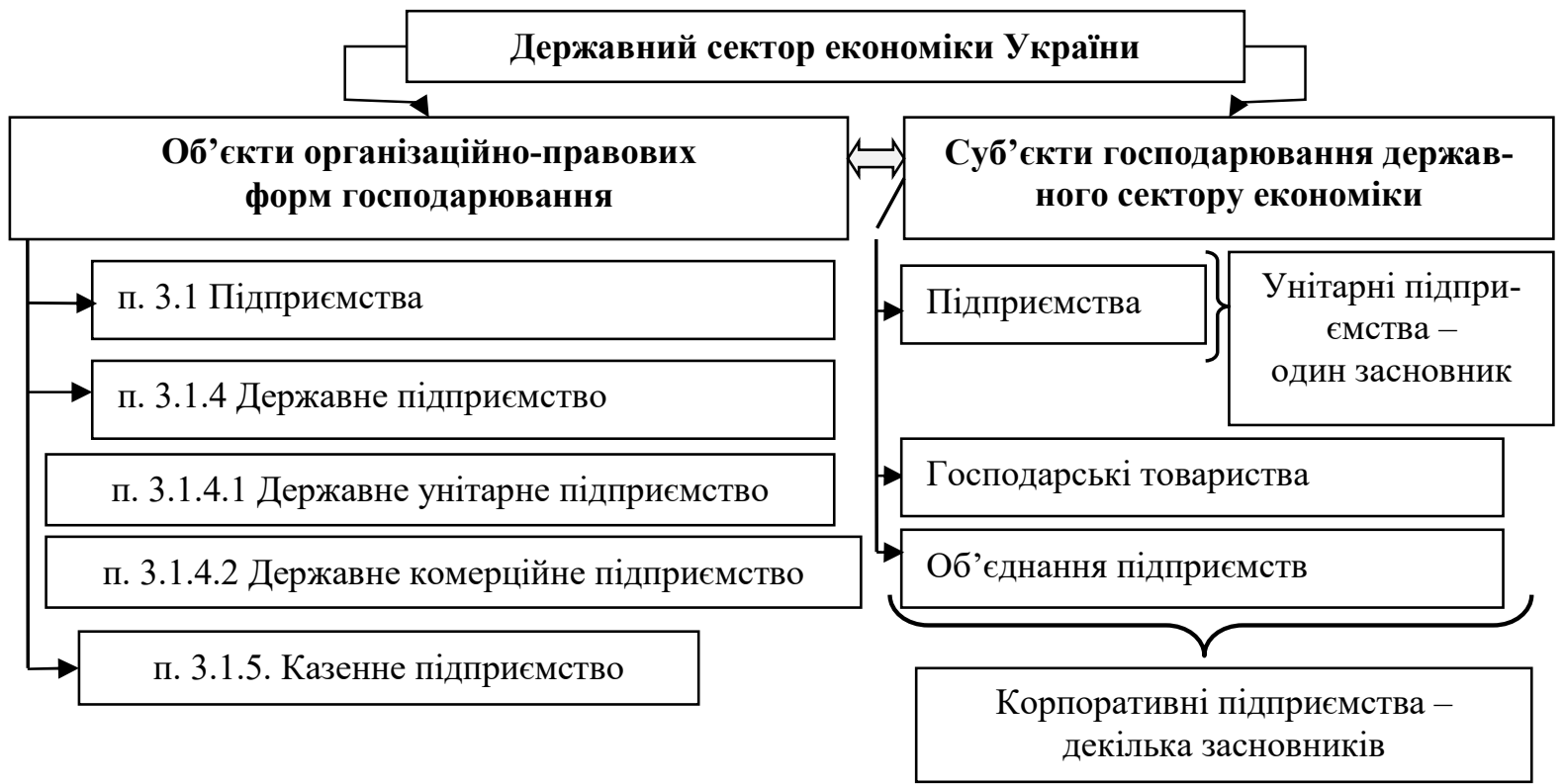

Рис. 2. Правові формати суб'єктів господарювання з державною часткою у статутному капіталі

При цьому суб'єктами господарювання державного сектору економіки є суб'єкти, що діють на основі лише державної власності, а також суб'єкти, державна частка у статутному фонді яких перевищує п'ятдесят відсотків чи становить величину, яка забезпечує державі право вирішального впливу на господарську діяльність цих суб'єктів.

Закордонна практика управління державною власністю свідчить, що вона може здійснюватися безпосередньо через власність акцій уряду, або опосередковано, коли акції утримуються державними структурами, такими як державні інвестиційні фонди, державні пенсійні фонди або центральні банки. Проте непряма участь зазвичай трапляється рідше. У деяких випадках, наприклад у Малайзії, Сінгапурі та країнах Західної Азії, державні інвестиційні фонди можуть мати частку більшості. Деякі державні інвестиційні фонди, наприклад урядовий пенсійний фонд Global, можуть мати значний вплив навіть через незначні пакети акцій (Cuervo-Cazurra, 2018). Нарешті, державна власність дедалі більше формується за допомогою багатьох акціонерів, поєднуючи державні інвестиційні фонди, пенсійні фонди та інші державні підприємства [9, с. 26]. 
ТЕОРЕТИЧНІ ПРОБЛЕМИ РОЗВИТКУ НАЦІОНАЛЬНОЇ ЕКОНОМІКИ

В Свропі багато відносно невеликих державних підприємств, які зазвичай мають кілька філій у сусідніх країнах через наявний інтегрований характер економіки регіону та невеликих національних територій [9]. Ці державні підприємства становлять майже половину державних підприємств із мажоритарною власністю та активами до 5 мільярдів доларів. У розвинених країнах багато великих державних підприємств були (частково або повністю) приватизовані у 90-х роках. У результаті державні підприємства в розвинених економіках поділяються на невеликі, які складають більшість, та великі, яких, здебільшого, декілька. Державні підприємства за кордоном мають різні назви - урядові корпорації, державні підприємства, державні компанії, напівдержавні підприємства, публічні підприємства, підрозділи чи підприємства державного сектору тощо. Крім назви, визначення державних підприємств також часто варіюється в різних країнах. За інформацією, поданою в межах звіту ОЕСР за 2012 рік та Огляду Світового банку латиноамериканських державних підприємств у 2014 році, управління ними класифіковано за трьома основними моделями власності [10, с. 7-8]:

1. Централізована модель, спрямована на узгодження практик нагляду та прозорості для державних підприємств шляхом встановлення узгодженої політики, ефективного розподілу людських ресурсів, чітких напрямів підзвітності та ретельного фіскального нагляду.

2.У подвійній або гібридній моделі відповідальність розподіляється між галузевим міністерством та одним або декількома централізованими міністерствами (Бразилія, Колумбія, Еквадор та Уругвай).

3. Децентралізована або галузева модель, покладає нагляд на декілька міністерств, які не мають повної координації з центрального органу, що здійснює нагляд за державними підприємствами в межах своєї галузевої політики (Аргентина, Коста-Рика та Мексика).

У розвиток зазначеного треба зауважити, що забезпечення ефективної нормативноправової бази для державних підприємств з позиції еталону ОЕСР передбачає [11, с. 71]:

1.Наявність чіткого поділу між функцією власності держави та іншими державними функціями, що може впливати на умови державних підприємств, особливо щодо регулювання ринку.

2. Прагнення Урядів спростити та впорядкувати оперативні практики та юридичну форму, в межах якої працюють державні підприємства. Їхня юридична форма повинна дозволяти кредиторам заявити свої вимоги та розпочати процедури неплатоспроможності.

3. Державні підприємства не повинні звільнятися від застосування загальних законів та правил.

4. Державні підприємства повинні здійснювати економічну діяльність за конкурентних умов щодо доступу до фінансів.

Враховуючи повільне зниження кількості державних підприємств у світі, вони залишаться важливим урядовим інструментом у будь-якій країні для створення суспільних цінностей за умови правильного соціально-економічного та політичного контексту.

Висновки і пропозиції. Регулювання створення та управління державних підприємств в Україні нині здійснюється відповідно до нормативно-правових актів Кабінету міністрів України, Господарського кодексу України, міжнародною Системи національних рахунків, Класифікації інституційних секторів економіки, Класифікатора організаційно-правових форм господарювання. Державні підприємства на сьогодні в Україні ще займають значну частку в структурі національної економіки та відносяться до суб'єктів господарювання державного сектору економіки, які провадять свою економічну діяльність як нефінансові корпорації. Закордонний досвід управління підприємствами 3 державною часткою в капіталі свідчить про тенденції до повільного їх скорочення загалом, проте з наявною потужною роллю у світовому господарстві. 
ТЕОРЕТИЧНІ ПРОБЛЕМИ РОЗВИТКУ НАЦІОНАЛЬНОЇ ЕКОНОМІКИ

\section{Список використаних джерел}

1. Тарасюк Г. М. Управління державними підприємствами: проблеми та перспективи. Bicник ЖДТУ. Серія: Економічні науки. 2014. № 4 (70). С. 111-118.

2. Білик М. Д. Управління фінансами державних підприємств: дис. ... д-ра екон. наук: 08.04.01 / ДВНЗ «УАБС НБУ». Суми, 2000. 404 с.

3. Гасанов С. С., Іваницька О. М., Кощук Т. В. Напрями підвищення фінансової стабільності державних підприємств в Україні. Фінанси України. 2015. № 12 (241). С. 48-62.

4. International Standard Industrial Classification of All Economic Activities. Statistical papers. Series M. 2008. No. 4, Rev. 4. URL: https://unstats.un.org/unsd/publication/seriesM/seriesm 4rev4e.pdf.

5. Про затвердження Класифікації інституційних секторів економіки України: Наказ Державної служби статистики Украӥни від 03.12.2014 № 378 URL: https://zakon.rada.gov.ua/rada/ show/v0378832-14.

6. Господарський кодекс України від 16.01.2003 № 436-IV URL: https://zakon.rada.gov.ua/ laws/show/436-15.

7. Реєстр (перелік) ФДМУ. Фонд державного майна України: веб-сайт. URL: http://www.spfu.gov.ua/ua/content/spf-stateproperty-Subiekti-gospodaruvannya.html.

8. Про затвердження національних стандартів України, державних класифікаторів України, національних змін до міждержавних стандартів, внесення зміни до наказу Держспоживстандарту України від 31 березня 2004 р. № 59 та скасування нормативних документів. Класифікатор організаційно-правових форм господарювання ДК 002:2004. Наказ від 28.05.2004 № 97 / Державний комітет України 3 питань технічного регулювання та споживчої політики. URL: https://zakon.rada.gov.ua/rada/show/v0097609-04.

9. World investment report (2019). Special economic zones. United Nations. URL: https://unctad.org/en/PublicationsLibrary/wir2019_overview_en.pdf.

10. Board practices and financing for latin American. State-owned enterprises. Report. November 2015. URL: https://www.oecd.org/daf/ca/Board-Practices-Financing-Latin-American-SOEs.pdf.

11. Governance of state-owned enterprises in the baltic states: public perceptions, regional \& national rankings of SOEs, board structures and composition, the legal and institutional framework for SOE governance. Baltic Institute of Corporate Governance. P. 115. URL: http://www.bicg.eu/wpcontent/uploads/2016/02/Governance-of-State-Owned-Enterprises-in-the-Baltic-States.pdf.

\section{References}

1. Tarasiuk, H. M. (2014). Upravlinnia derzhavnymy pidpryiemstvamy: problemy ta perspektyvy [Management of state-owned enterprises: problems and prospects]. Visnyk ZhDTU. Seriia: Ekonomichni nauky - ZhSTU Bulletin. Series: Economic Sciences, 4(70), 111-118 [in Ukrainian].

2. Bilyk, M. D. (2000). Upravlinnia finansamy derzhavnykh pidpryiemstv [Management of finances of state-owned enterprises]. (Extended abstract of the Doctor's thesis). DVNZ «UABS NBU», Sumy [in Ukrainian].

3. Hasanov, S. S., Ivanytska, O. M., Koshchuk, T. V. (2015). Napriamy pidvyshchennia finansovoi stabilnosti derzhavnykh pidpryiemstv v Ukraini [Directions for improving the financial stability of state-owned enterprises in Ukraine]. Finansy Ukrainy - Finance of Ukraine, 12(241), 48-62 [in Ukrainian].

4. International Standard Industrial Classification of All Economic Activities. Statistical papers. Series M. 2008. No. 4, Rev. 4. Retrieved from https:/unstats.un.org/unsd/publication/seriesM/ seriesm_4rev4e.pdf.

5. Pro zatverdzhennia Klasyfikatsii instytutsiinykh sektoriv ekonomiky Ukrainy [On approval of the Classification of Institutional Sectors of the Ukrainian Economy]. № 378 (03.12.2014). Retrieved from https://zakon.rada.gov.ua/rada/show/v0378832-14.

6. Hospodarskyi kodeks Ukrainy [Economic Code of Ukraine]. № 436-IV (16.01.2003). Retrieved from https://zakon.rada.gov.ua/laws/show/436-15.

7. Reiestr (perelik) FDMU [Register (list) SPFU]. Retrieved from http://www.spfu.gov.ua/ua/ content/spf-stateproperty-Subiekti-gospodaruvannya.html. 
ТЕОРЕТИЧНІ ПРОБЛЕМИ РОЗВИТКУ НАЦІОНАЛЬНОЇ ЕКОНОМІКИ

8. Pro zatverdzhennia natsionalnykh standartiv Ukrainy, derzhavnykh klasyfikatoriv Ukrainy, natsionalnykh zmin do mizhderzhavnykh standartiv, vnesennia zminy do nakazu Derzhspozhyvstandartu Ukrainy vid 31 bereznia 2004 r. № 59 ta skasuvannia normatyvnykh dokumentiv. Klasyfikator orhanizatsiino-pravovykh form hospodariuvannia DK 002:2004 [On approval of national standards of Ukraine, state classifiers of Ukraine, national changes to interstate standards, introduction of amendments to the Order of the State Consumer Standard of Ukraine of March 31, 2004 No. 59 and repeal of normative documents. Classifier of organizational and legal forms of management DK 002: 2004]. No 97 (28.05.2004). Retrieved from https://zakon.rada.gov.ua/ rada/show/v0097609-04.

9. World investment report (2019). Special economic zones. United Nations. Retrieved from https://unctad.org/en/PublicationsLibrary/wir2019_overview_en.pdf.

10. Board practices and financing for latin American. State-owned enterprises. Report. November 2015. Retrieved from https://www.oecd.org/daf/ca/Board-Practices-Financing-Latin-American-SOEs.pdf.

11. Governance of state-owned enterprises in the baltic states: public perceptions, regional \& national rankings of SOEs, board structures and composition, the legal and institutional framework for SOE governance. Baltic Institute of Corporate Governance (p. 115). Retrieved from http://www.bicg.eu/wp-content/uploads/2016/02/Governance-of-State-Owned-Enterprises-in-theBaltic-States.pdf.

Чумак Оксана Володимирівна - кандидат економічних наук, доцент, доцент кафедри фінансів, банківської та страхової справи, ПрАТ «Вищий навчальний заклад “Міжрегіональна академія управління персоналом”» (вул. Фрометівська, 2, м. Київ, 03039, Україна).

Чумак Оксана Владимировна - кандидат экономических наук, доцент, доцент кафедры финансов, банковского и страхового дела, ЧАО «Высшее учебное заведение "Межрегиональная академия управления персоналом"» (ул. Фрометовская, 2, г. Киев, 03039, Украина).

Chumak Oksana - PhD in Economics, Associate Professor, Associate Professor of Department of Finance, Banking and Insurance, PJSC Higher education institution Interregional Academy of Personnel Management (2 Frometovskaia Str., 03039 Kyiv, Ukraine).

E-mail: chumak_ov@i.ua

ORCID: https://orcid.org/0000-0001-6387-2840 